\title{
ANALISIS SEKTOR UNGGULAN DAN SPESIALISASI REGIONAL KOTA BANDAR LAMPUNG
}

\author{
${ }^{1)}$ Dwi Mahroji ${ }^{2)}$ Mei Indrawati \\ 1) Dosen Program Studi Ekonomi Pembangunan, STIE Pandu Madania,d_mahroji@yahoo.com \\ 2) Mahasiswa Program Studi Ekonomi Pembangunan, STIE Pandu Madania
}

\begin{abstract}
ABSTRAK
Pertumbuhan ekonomi adalah salah satu tolak ukur yang dapat dipakai untuk meningkatkan adanya pembangunan suatu daerah dari berbagai macam sektor ekonomi yang secara tidak langsung menggambarkan tingkat perubahan ekonomi. Pembangunan daerah harus sesuai dengan kondisi potensi serta aspirasi masyarakat yang tumbuh dan berkembang. Apabila pelaksanaan prioritas pembangunan daerah kurang sesuai dengan potensi yang dimiliki oleh masing-masing daerah, maka pemanfaatan sumberdaya yang ada akan menjadi kurang optimal. Penelitian ini bertujuan untuk mengidentifikasi sektor-sektor unggulan dan spesialisasi regional di Kota Bandar Lampung. Data yang digunakan dalam penelitian ini adalah data sekunder kurun waktu tahun 2008-2012 bersumber dari BPS Provinsi, dan BPS Kota. Model analisis yang digunakan yakni Analisis LQ, Tipologi Klassen dan Analisis Spesialisasi Regional. Hasil penelitian menunjukkan bahwa terdapat tujuh sektor basis pada perekonomian Kota Bandar Lampung antara lain sektor industri pengolahan, sektor listrik, gas dan air bersih, sektor bangunan, sektor perdagangan, hotel dan restoran, sektor angkutan/komunikasi, sektor bank dan lembaga keuangan lainnya, dan sektor jasa-jasa. Sedangkan hasil analisis Tipologi Klassen, sektor yang merupakan sektor unggulan pada perekonomian Kota Bandar Lampung terdapat satu sektor unggulan yaitu sektor industri pengolahan. Namun, tidak terdapat spesialisasi regional di Kota Bandar Lampung.
\end{abstract}

Kata Kunci: Sektor Unggulan, Spesialisasi Regional, Tipologi Klassen

\begin{abstract}
Economic growth is one of the benchmarks that can be used to increase the development of an area of various economic sectors which indirectly illustrates the level of economic change. Regional development must be in accordance with the conditions of the potential and aspirations of people who grow and develop. If the implementation of regional development priorities is not in accordance with the potential of each region, the utilization of available resources will be less than optimal. This study aims to identify leading sectors and regional specializations in Bandar Lampung City. The data used in this study are secondary data from 2008-2012 sourced from the Provincial BPS and City BPS. The analysis model used is LQ Analysis, Klassen Typology and Regional Specialization Analysis. The results showed that there were seven basic sectors in the Bandar Lampung City economy including the manufacturing sector, the electricity, gas and water supply sector, the construction sector, the trade, hotel and restaurant sector, the transportation / communication sector, the banking sector and other financial institutions, and service sector. While the Klassen Typology analysis results, there is one leading sector in the economy of Bandar Lampung City, namely the manufacturing sector. However, there is no regional specialization in Bandar Lampung City.

Keywords: leading sector, regional specialization, klassen typology
\end{abstract}




\section{PENDAHULUAN}

Glasson (1990) mengatakan bahwa kemakmuran suatu wilayah berbeda dengan wilayah lainnya.Perubahan wilayah kepada kondisi yang lebih makmur tergantung pada usaha-usaha didaerah tersebut dalam menghasilkan barang dan jasa, serta usaha-usaha pembangunan yangdiperlukan.

Kota Bandar Lampung sebagai kota terbesar dan tersibuk di Provinsi Lampung memiliki aktivitas ekonomi yang sangat tinggi. Peningkatan ekonomi kota semestinya membawa dampak yang signifikan bagi seluruh masyarakat kota termasuk masyarakat pesisir. Kenyataan menunjukkan sebaliknya, terdapat ketimpangan-ketimpangan pembangunan antara pusat kota dan hinterland-nya. Banyak permasalahan yang terjadi di desa-desa pesisir akibat belum optimalnya arahan pengembangan desa-desa pesisir tersebut.

Proyek pengembangan daerah terpadu yang dilakukan oleh Kementrian Dalam Negeri, di bawah Direktorat Pembangunan Daerah yang melibatkan dua pulau yaitu Pulau Sumatera dan PulauKalimantan, menjadikan Provinsi Lampung perlu melihat kembali sektor mana yang menjadi sektor strategis dan menjadi unggulan, serta memiliki daya saing yang cukup tinggi khususnya untuk setiapkabupaten maupun kota. Dalam penelitian ini hanya mengkaji sektorsektor di Kota Bandar Lampung. Dengan demikian, dalam penelitian ini ingin mempertanyakan apakah yang menjadi sektor unggulan di Kota Bandar Lampung?

Berdasarkan uraian di atas, penelitian ini untuk mengidentifikasi sektor unggulan di Kota Bandar Lampung dan menentukan tingkat spesialisasi Kota Bandar Lampung.

\section{KAJIAN LITERATUR \\ Teori Basis Ekonomi}

Dalam teori basis ekonomi (economic base) mengemukakan bahwa sebuah wilayah merupakan sebuah sistem sosio-ekonomi yang terpadu.Teori inilah yang mendasari pemikiran teknik location quotient, yaitu teknik yang membantu dalam menentukan kapasitas ekspor perekonomian daerah dan derajat keswasembadaan (Self-sufficiency) suatu sektor.

\section{Analisis Location Quotient (LQ)}

Kadariah (1985) mengemukakan bahwa, secara umum location quotient dapat dirumuskan sebagai berikut:

Jika:

vi : Pendapatan dari industri/sektor i di suatu daerah (kabupaten)

$\mathrm{vt}$ : pendapatan total di daerah tersebut (kabupaten)

Vi : Pendapatan dari industri/sektor i di daerah yang lebih luas (provinsi)

$\mathrm{Vt}$ : Pendapatan total di seluruh daerah yang lebih luas (provinsi)

Maka industri/sektor i di daerah itu mempunyai location quotient sebesar:

$$
L Q=\frac{v i / v t}{V i / V t} \text { atau } L Q=\frac{v i / V i}{v t / V t}
$$

Kriteria yang digunakan adalah:

- $\quad$ LQ > 1 menunjukkan bahwa sektor tersebut basis

- $\quad$ LQ $<1$ menunjukkan bahwa sektor tersebut nonbasis

\section{Analisis Tipologi Klassen}

Tipologi Klassen merupakan alat analisis yang dapat digunakan untuk mengidentifikasi sektor, subsektor, usaha, atau komoditi prioritas atau unggulan suatu daerah. 
Klasifikasi sektor PDRB menurut Tipologi Klassen sebagaimana tercantum pada Tabel 2.1.

Tabel 1. Klasifikasi Sektor PDRB Menurut Tipologi Klassen

\begin{tabular}{cc}
\hline Kuadran I & Kuadran II \\
\hline $\begin{array}{c}\text { Sektor yang maju dan tumbuh dengan pesat } \\
\text { (developed sector) } \mathrm{s}_{\mathrm{i}}>\mathrm{s} \text { dan } \mathrm{sk}_{\mathrm{i}}>\mathrm{sk}\end{array}$ & $\begin{array}{c}\text { Sektor maju tapi tertekan (stagnant sector) } \\
\mathrm{s}_{\mathrm{i}}<\mathrm{s} \text { dan } \mathrm{sk}_{\mathrm{i}}>\mathrm{sk}\end{array}$ \\
\hline Kuadran III & Kuadran IV \\
\hline $\begin{array}{c}\text { Sektor potensial atau masih dapat berkembang } \\
\text { (developing sector) } \mathrm{s}_{\mathrm{i}}>\mathrm{s} \text { dan } \mathrm{sk}_{\mathrm{i}}<\mathrm{sk}\end{array}$ & $\begin{array}{c}\text { Sektor relatif tertinggal (underdeveloped } \\
\text { sector) } \mathrm{s}_{\mathrm{i}}<\mathrm{s} \text { dan } \mathrm{s}_{\mathrm{i}}<\mathrm{sk}\end{array}$
\end{tabular}

Sumber: Sjafrizal, 2008

\section{Konsep Spesialisasi dan Pembagian Kerja}

Menurut Samuelson dan Nordhaus (1995) masyarakat dapat lebih efektif dan efisien jika terdapat pembagian kerja yang membagi keseluruhan proses produksi menjadi unit-unit khusus yang terspesialisasi. Ekonomi spesialisasi telah memungkinkan terbentuknya jaringan perdagangan antarindividu dan antarnegara yang demikian luas, yang merupakan ciri dari suatu perekonomian maju. Adanya keterkaitan ekonomi (spesialisasi) antardaerah yang mendorong proses pertukaran sesuai kebutuhan masing-masing, akan memungkinkan bergeraknya perekonomian masing-masing daerah secara bersama-sama menuju proses pertumbuhan.

\section{Kerangka Konseptual dan Hipotesis}

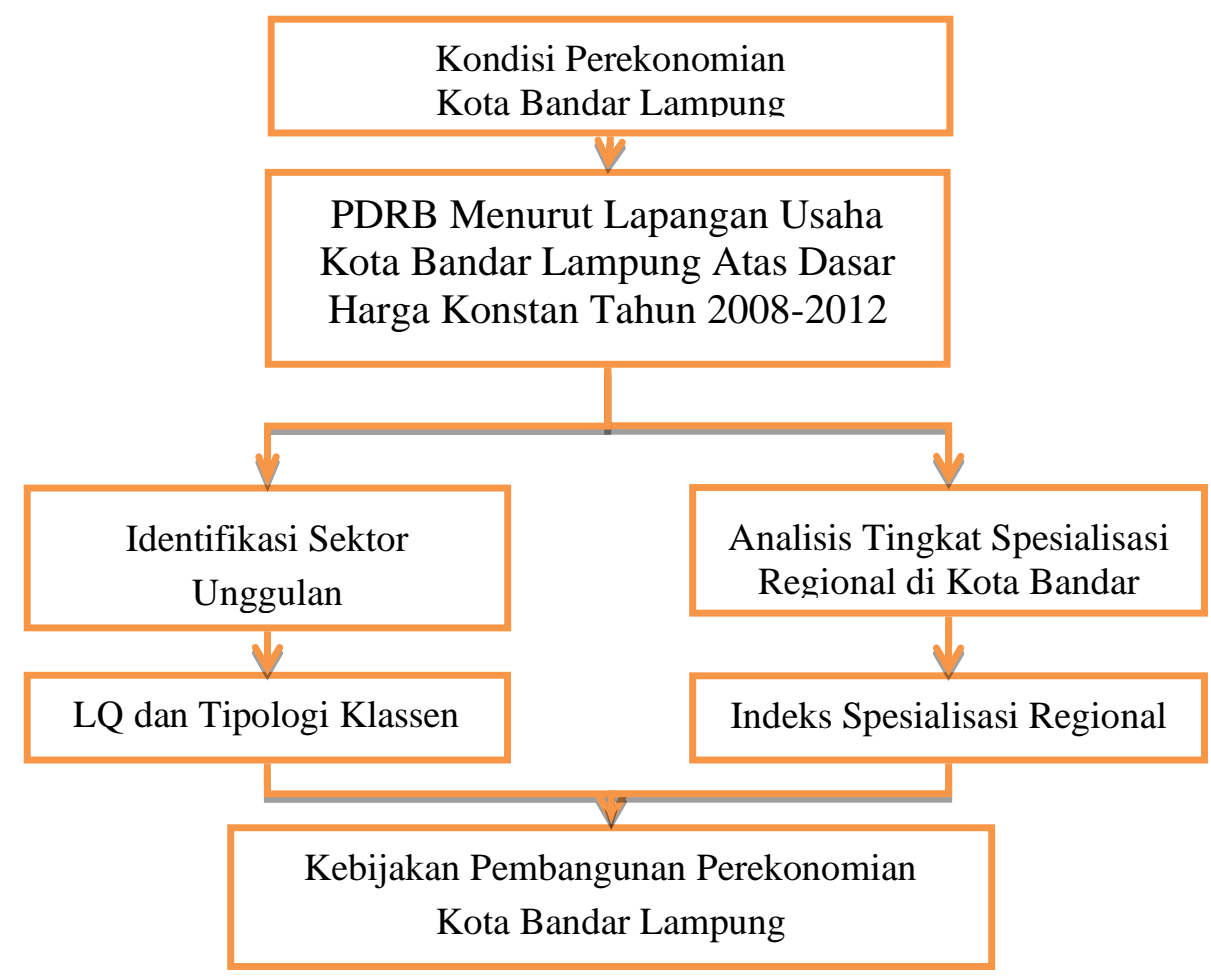

Gambar 1. Kerangka Pemikiran 


\section{METODE PENELITIAN}

Objek penelitian ini antara lain sektor unggulan dan spesialisasi regional. Penelitian ini mengambil lokasi di Kota Bandar Lampung. Hal tersebut dikarenakan Kota Bandar Lampung memiliki potensi dalam pertumbuhan ekonomi akan tetapi masih belum bisa melepaskan diri dari masalah kemiskinan. Oleh karena itu, diharapkan hasil penelitian ini di masa yang akan datang dapat menjadi bahan pertimbangan dalam pembangunan ekonomi di Kota Bandar Lampung. Tabel 2 berikut ini menjelaskan tentang operasionalisasi variable dalam penelitian ini:

Tabel 2. Operasionalisasi Variabel

\begin{tabular}{|c|c|c|c|c|}
\hline No & Variabel & KONSEP & INDIKATOR & SKALA \\
\hline 1 & $\begin{array}{l}\text { Pertumbuhan } \\
\text { Ekonomi }\end{array}$ & $\begin{array}{c}\text { Kenaikan jangka panjang } \\
\text { dalam kemampuan suatu } \\
\text { negara (daerah) untuk } \\
\text { menyediakan semakin } \\
\text { banyak barang-barang } \\
\text { ekonomi kepada } \\
\text { penduduknya; kemampuan } \\
\text { ini tumbuh sesuai dengan } \\
\text { kemajuan teknologi, dan } \\
\text { penyesuaian kelembagaan } \\
\text { dan ideologis yang } \\
\text { diperlukannya }\end{array}$ & $\begin{array}{c}\text { Perubahan } \\
\text { PDRB dari } \\
\text { Tahun ke Tahun }\end{array}$ & Rasio \\
\hline 2 & $\begin{array}{l}\text { PDRB } \\
\text { Persektor }\end{array}$ & $\begin{array}{l}\text { Nilai tambah yangterbentuk } \\
\text { dari keseluruhan kegiatan } \\
\text { ekonomidalam suatu } \\
\text { wilayah dengan rentang } \\
\text { waktutertentu. }\end{array}$ & $\begin{array}{l}\text { Produk Regional } \\
\text { pada setiap } \\
\text { sektor ekonomi }\end{array}$ & Rasio \\
\hline
\end{tabular}

Data-data yang digunakan dalam penelitian ini bersumber dari Badan Pusat Statistik (BPS) Kota Bandar Lampung dan Provinsi Lampung. Jenis data berupa data sekunder mengenai PDRB atas dasar harga konstan dan data-data lainnya yang mendukung penelitian ini.

Pengumpulan data dalam suatu penelitian dimaksudkan untuk memperoleh bahan-bahan yang relevan, akurat dan realistis. Metode pengumpulan data yang digunakan pada penelitian ini melalui literatur dengan menggunakan media massa (internet).

Untuk menjawab permasalahan yang telah ditetapkan, maka digunakan beberapa metode analisis data, yaitu:

1. Analisis Location Quotient (LQ) digunakan untuk menentukan sektor basis dan nonbasis dalam perekonomian wilayah Kota Bandar Lampung. Analisis Tipologi Klassen digunakan untuk memperoleh klasifikasi pertumbuhan sektor perekonomian wilayah Kota Bandar Lampung.

2. Analisis Indeks Spesialisasi digunakan untuk mengetahui tingkat spesialisasi sektor lapangan usaha antardaerah di wilayah Kota Bandar Lampung.

PEMBAHASAN

Gambaran Umum Lokasi Penelitian 
Kota Bandar Lampung merupakan Ibukota dari Provinsi Lampung dan merupakan pusat kegiatan pemerintahan, sosial, politik, pendidikan dan kebudayaan serta kegiatan perekonomian. Secara geografis terletak pada $5^{0} 20^{\prime}$ 'sampai dengan $5^{0} 30^{\prime}$ Lintang Selatan dan $105^{\circ} 28^{\prime}$ 'sampai dengan 105 $37^{\prime}$ 'Bujur Timur. Ibukota Bandar Lampung berada di Teluk Betung yang terletak di ujung selatan Pulau Sumatera, memiliki luas wilayah daratan $19.722 \mathrm{Ha}\left(197,22 \mathrm{~km}^{2}\right)$ dan luas perairan kurang lebih $39,82 \mathrm{~km}^{2}$.

\section{Klasifikasi Sektor Basis dan Nonbasis di Kota Bandar Lampung}

Tabel 3. Hasil Analisis Location Quotient (LQ) Kota Bandar Lampung Tahun 2008-2012

\begin{tabular}{|c|c|c|c|c|c|c|c|c|}
\hline \multirow[b]{2}{*}{ No } & \multirow[b]{2}{*}{ Lapangan Usaha } & \multicolumn{5}{|c|}{ Nilai LQ } & \multirow{2}{*}{$\begin{array}{l}\text { Rata- } \\
\text { Rata } \\
\text { LQ }\end{array}$} & \multirow{2}{*}{$\begin{array}{c}\text { Keteranga } \\
\text { n }\end{array}$} \\
\hline & & 2008 & 2009 & 2010 & 2011 & 2012 & & \\
\hline 1 & Pertanian & 0,10 & 0,11 & 0,11 & 0,11 & 0,11 & 0,11 & NonBasis \\
\hline 2 & Pertambangan & 0,58 & 0,67 & 0,70 & 0,66 & 0,66 & 0,65 & NonBasis \\
\hline 3 & Industri Pengolahan & 1,37 & 1,36 & 1,38 & 1,40 & 1,41 & 1,39 & Basis \\
\hline 4 & Listrik dan Air Bersih & 1,84 & 1,88 & 1,73 & 1,67 & 1,56 & 1,73 & Basis \\
\hline 5 & Bangunan & 1,57 & 1,57 & 1,54 & 1,52 & 1,50 & 1,54 & Basis \\
\hline 6 & $\begin{array}{c}\text { Perdagangan, Hotel, } \\
\text { Restoran }\end{array}$ & 1,14 & 1,11 & 1,08 & 1,09 & 1,07 & 1,10 & Basis \\
\hline 7 & Angkutan/Komunikasi & 2,43 & 2,29 & 2,12 & 2,00 & 1,88 & 2,14 & Basis \\
\hline 8 & Bank/Keu/Perum & 2,56 & 2,38 & 2,10 & 2,08 & 2,09 & 2,24 & Basis \\
\hline 9 & Jasa & 1,92 & 1,91 & 1,89 & 1,86 & 1,76 & 1,87 & Basis \\
\hline
\end{tabular}

Sumber: Data diolah.

Berdasarkan Tabel 3 dari hasil perhitungan indeks Location Quotient PDRB Kota Bandar Lampung selama periode pengamatan tahun 2008-2012, maka dapat teridentifikasi sektor-sektor basis dan nonbasis. Kontribusi sektor angkutan/komunikasi dan sektor Bank/Lembaga Keuangan sangat besar terhadap PDRB Kota Bandar Lampung, dengan LQ rata-rata berturutturut sebesar 2,14 dan 2,24. Hal ini menunjukkan sektor angkutan/komunikasi dan sektor Bank/Lembaga Keuangan merupakan sektor basis yang memiliki kekuatan ekonomi yang cukup baik dan sangat berpengaruh terhadap peningkatan pertumbuhan ekonomi Kota Bandar Lampung.

\section{Klasifikasi Pertumbuhan Sektor Perekonomian di Kota Bandar Lampung}

Tabel 4. Laju Pertumbuhan dan Kontribusi Sektor PDRB Provinsi Lampung dan Kota Bandar Lampung Tahun 2008-2012

\begin{tabular}{ccccc}
\hline \multirow{2}{*}{ Sektor } & \multicolumn{2}{c}{ Prov. Lampung } & \multicolumn{2}{c}{ Kota Bandar Lampung } \\
\cline { 2 - 5 } & $\begin{array}{c}\text { Rataan } \\
\text { Pertumbuhan }\end{array}$ & $\begin{array}{c}\text { Rataan } \\
\text { Kontribusi }\end{array}$ & $\begin{array}{c}\text { Rataan } \\
\text { Pertumbuhan }\end{array}$ & $\begin{array}{c}\text { Rataan } \\
\text { Kontribusi }\end{array}$ \\
\cline { 2 - 5 } $\mathbf{S}$ & Sk & Si & Ski \\
\hline Pertanian & 3,22 & 39,25 & 2,00 & 3,94 \\
Pertambangan & 0,79 & 2,03 & 2,85 & 1,27 \\
Industri Pengolahan & 5,32 & 13,33 & 6,03 & 18,35 \\
Listrik dan Air Bersih & 8,41 & 0,38 & 2,39 & 0,62 \\
Bangunan & 5,54 & 4,84 & 3,41 & 7,22 \\
Perdagangan, Hotel, & 5,87 & 15,84 & 3,48 & 16,85 \\
Restoran & 13,37 & 7,27 & 6,94 & 15,52 \\
Angkutan/Komunikasi & 14,93 & 9,42 & 12,23 & 22,38 \\
Bank/Keu/Perum & & &
\end{tabular}




\begin{tabular}{ccccc} 
Jasa & 7,21 & 7,65 & 3,85 & 13,86 \\
\hline Sumber: Data diolah. & &
\end{tabular}

Selain itu, dari tingkat provinsi sektor-sektor yang memiliki kontribusi rata-rata paling besar adalah sektor pertanian, sektor perdagangan hotel dan restoran, dan sektor industri pengolahan. Sedangkan sektor yang menyumbangkan kontribusi rata-rata paling kecil, yaitu sektor listrik, gas dan air bersih. Pertumbuhan rata-rata Provinsi Lampung paling tinggi adalah sektor bank dan lembaga keuangan lainnya diikuti sektor pengangkutan dan komunikasi. Sementara sektor pertambangan dan penggalian mempunyai pertumbuhan paling kecil.

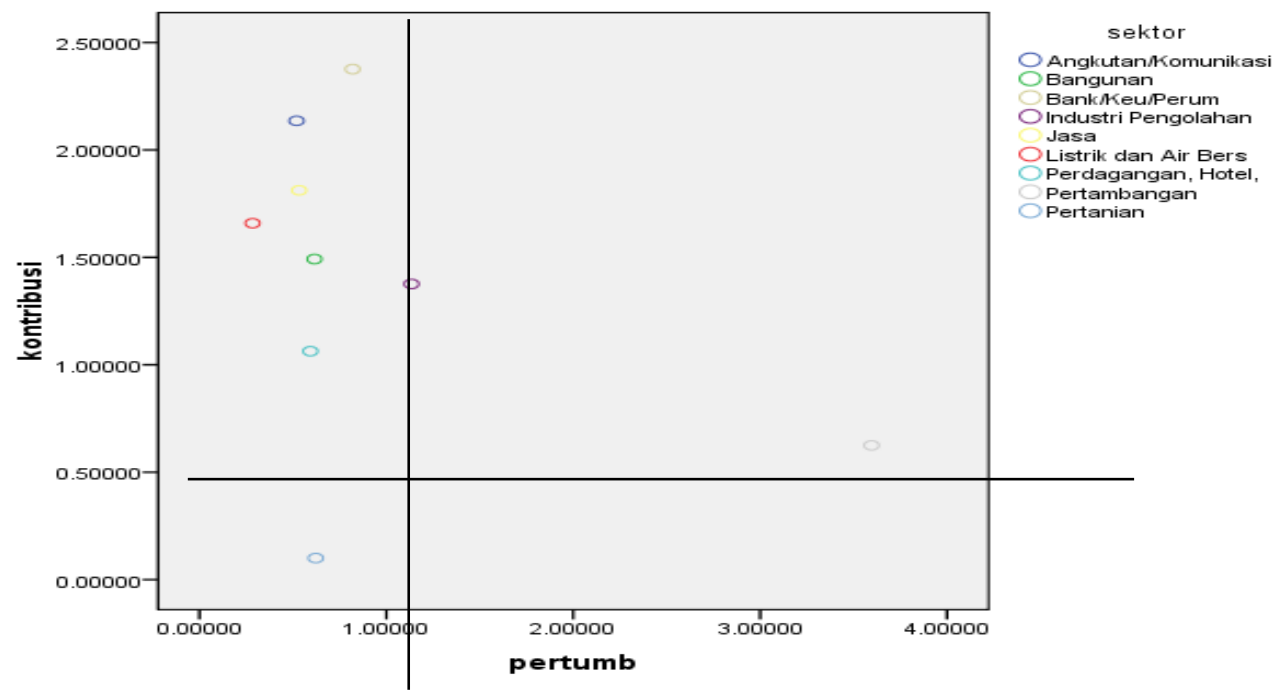

Sumber: data diolah.`

Gambar 2. Klasifikasi Sektor Ekonomi Kota Bandar Lampung Berdasarkan Tipologi Klassen

Melalui Gambar 2 tersebut dapat dijelaskan secara ringkas pada Tabel 5 berikut ini:

Tabel 5. Klasifikasi Sektor PDRB Kota Bandar Lampung Tahun 2008-2012 Berdasarkan Tipologi Klassen

\begin{tabular}{ll}
\hline Kuadran I & Kuadran II \\
\hline Sektor yang maju dan tumbuh dengan pesat & Sektor maju tapi tertekan (stagnant sector) \\
(developed sector) $\mathrm{s}_{\mathrm{i}}>\mathrm{s}$ dan $\mathrm{sk}_{\mathrm{i}}>\mathrm{sk}$ & \multicolumn{1}{c}{$\mathrm{s}_{\mathrm{i}}<\mathrm{s}$ dan $\mathrm{sk} \mathrm{k}_{\mathrm{i}}>\mathrm{sk}$} \\
- Sektor Industri Pengolahan & - Listrik dan Air Bersih \\
& - Bangunan \\
& - Perdagangan, Hotel, Restoran \\
& - Angkutan/Komunikasi \\
& - Jank/Keu/Perum \\
\hline Kuadran III & Kuadran IV \\
\hline Sektor potensial atau masih dapat berkembang & Sektor relatif tertinggal (underdeveloped \\
$\quad$ (developing sector) $\mathrm{s}_{\mathrm{i}}>\mathrm{s}$ dan $\mathrm{sk}_{\mathrm{i}}<\mathrm{sk}$ & sector) $\mathrm{s}_{\mathrm{i}}<\mathrm{s}$ dan $\mathrm{sk}_{\mathrm{i}}<\mathrm{sk}$ \\
- Sektor Pertambangan & - Sektor Pertanian \\
\hline Sumber: Data diolah &
\end{tabular}

Sesuai hasil analisis pada Tabel 5 terhadap PDRB Kota Bandar Lampung, hanya terdapat satu sektor yang dapat dikategorikan sebagai sektor maju dan tumbuh pesat, yaitu 
sektor industri pengolahan. Sementara itu, sektor listrik dan air bersih, sektor bangunan, sektor perdagangan, hotel dan restoran, sektor angkutan/komunikasi, sektor bank dan lembaga keuangan lainnya, dan sektor jasa-jasa termasuk ke dalam sektor maju tapi tertekan, walaupun sektor-sektor tersebut memiliki kontribusi yang paling besar tetapi pertumbuhan rata-rata tidak mengalami perkembangan. Sektor-sektor yang tergolong ke dalam sektor potensial untuk berkembang adalah sektor pertambangan.Kemudian sektor yang relatif tertinggal adalah sektor pertanian. Ternyata hasil analisis menunjukkan banyak sektor-sektor di Kota Bandar Lampung tergolong ke dalam sektor maju tetapi tertekan, yaitu sektor listrik dan air bersih, sektor bangunan, sektor perdagangan, hotel dan restoran, sektor angkutan/komunikasi, sektor bank dan lembaga keuangan lainnya, dan sektor jasa-jasa.

\section{Spesialisasi Regional}

Tabel 6. Indeks Spesialisasi Regional Kota Bandar Lampung Tahun 2008-2012

\begin{tabular}{ccccccc}
\hline \multirow{2}{*}{ Sektor } & \multicolumn{9}{c}{ Indeks Spesialisasi } & Rata-Rata \\
\cline { 2 - 6 } & $\mathbf{2 0 0 8}$ & $\mathbf{2 0 0 9}$ & $\mathbf{2 0 1 0}$ & $\mathbf{2 0 1 1}$ & $\mathbf{2 0 1 2}$ & Indeks \\
\hline Pertanian & 0,37 & 0,36 & 0,35 & 0,34 & 0,33 & 0,35 \\
Pertambangan & 0,01 & 0,01 & 0,01 & 0,01 & 0,01 & 0,01 \\
Industri Pengolahan & 0,05 & 0,05 & 0,05 & 0,05 & 0,05 & 0,05 \\
Listrik dan Air Bersih & 0,00 & 0,00 & 0,00 & 0,00 & 0,00 & 0,00 \\
Bangunan & 0,03 & 0,03 & 0,03 & 0,02 & 0,02 & 0,03 \\
Perdagangan, Hotel, Restoran & 0,02 & 0,02 & 0,01 & 0,01 & 0,01 & 0,01 \\
Angkutan/Komunikasi & 0,09 & 0,09 & 0,08 & 0,08 & 0,07 & 0,08 \\
Bank/Keu/Perum & 0,12 & 0,12 & 0,11 & 0,11 & 0,12 & 0,12 \\
Jasa & 0,07 & 0,07 & 0,07 & 0,07 & 0,06 & 0,07 \\
\hline
\end{tabular}

Sumber: Data diolah

Tabel 6 menunjukkan hasil dari analisis spesialisasi regional pada beberapa lapangan usaha di Kota Bandar Lampung dan Provinsi Lampung tahun 2008-2012. Berdasarkan hasil analisis tersebut, diketahui bahwa semua sektor di Kota Bandar Lampung memiliki indeks spesialisasi mendekati nol. Hal tersebut menunjukkan bahwa, Kota Bandar Lampung tidak memiliki spesialisasi dalam bidang ekonomi.

Sektor pertanian merupakan sektor yang memiliki rata-rata indeks spesialisasi paling tinggi selama lima tahun terakhir, yaitu sebesar 0,35. Akan tetapi, sektor tersebut di Kota Bandar Lampung tidak memberikan kontribusi yang signifikan dalam PDRB Kota Bandar Lampung dan pertumbuhannya relatif tertinggal apabila dibandingkan dengan sektor-sektor lainnya.

\section{PENUTUP}

Sektor-sektor yang merupakan sektor basis pada perekonomian Kota Bandar Lampung antara lain sektor industri pengolahan, sektor listrik, gas dan air bersih, sektor bangunan, sektor perdagangan, hotel dan restoran, sektor angkutan/komunikasi, sektor bank dan lembaga keuangan lainnya, dan sektor jasa-jasa. Sedangkan hasil analisis Tipologi Klassen, sektor yang merupakan unggulan pada perekonomian Kota Bandar Lampung yaitu sektor industri pengolahan. Berdasarkan pada hasil analisis spesialisasi regional, Kota Bandar Lampung tidak memiliki spesialisasi karena hasil analisis spesialisasi regional menunjukkanbahwa sektor perekonomian di Kota Bandar Lampung memiliki nilai indeks spesialisasi regional mendekati nol. 
Kota Bandar Lampung memiliki tujuh sektor basis dari sembilan sektor yang ada pada PDRB Kota Bandar Lampung. Pemerintah Daerah Kota Bandar Lampung perlu memberikan perhatian khusus pada sektor-sektor tersebut, khususnya untuk sektor unggulan. Dengan demikian, daya saing Kota Bandar Lampung dapat ditingkatkan. Sektor-sektor ekonomi yang berpotensial hendaknya lebih dikembangkan lagi sehingga di masa-masa yang akan datang sektor-sektor ekonomi tersebut dapat diandalkan untuk kontribusi perekonomian.

\section{REFERENSI}

Armida,S. Alisyahbana. 2000. Desentralisasi Fiskal dan Kebijakan Pembangunan Ekonomi Daerah: Makalah disampaikan pada kongres ISEI XIV, 21-23 April, di Makasar.

Arsyad, Lincolin. 1999. Pengantar Perencanaan dan Pembangunan Ekonomi Daerah. BPFE, Yogyakarta.

Azis, Iwan J. 1994. Ilmu Ekonomi Regional dan Beberapa Aplikasinya di Indonesia,Lembaga Penerbit FE UI, Jakarta.

Badan Pusat Statistik (BPS). 2012. Produk Domestik Regional Bruto (PDRB) ProvinsiLampung.http://lampung.bps.go.id/publikasi/buku/pdrblapusaha2012/index.ht

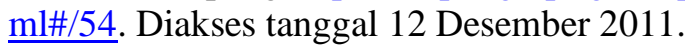

. 2010. Lampung Dalam Angka. BPS Provinsi Lampung. http://bandarlampungkota.bps.go.id. Diakses tanggal 12 Desember 2011.

Boediono. 2004. Teori Pertumbuhan Ekonomi. Yogyakarta: BPFE.

Glasson, John. 1990. Pengantar Perencanaan Regional, Terjemahan Paul Sitohang, Lembaga Penerbit FE UI, Jakarta.

Jhingan, M.L. 2002. Ekonomi Pembangunan dan Perencanaan. Jakarta: PT. Raja Grafindo Persada.

Kadariah. 1985. Ekonomi Perencanaan. LPFE Universitas Indonesia.

Kim, S. 1995. Expansion of Markets and The Geographic Distribution of Economic Activities :

The Trends in U.S. Regional Manufacturing Structure 1860-1987. Quartely Journal of Economics. Vol. 10, p.881-908.

Samuelson, Paul A, Nordhaus and William D. 1996. Maroekonomi. Jakarta : Erlangga.

Sjafrizal. 2008. Ekonomi Regional, Teori dan Aplikasi, Baduose Media, Cetakan Pertama, Padang.

Sukirno, Sadono. 1985. Ekonomi Pembangunan: Proses, Masalah dan dasarKebijakan, LPFEUI, Jakarta.

Sukirno, Sadono. 1994. Pengantar Teori Makro Ekonomi. Jakarta: PT. Raja Grafindo Persada.

Tarigan, Robinson. 2007. Ekonomi Regional, Teori dan Aplikasi, PT. Bumi Aksara, Cetakan Keempat, Jakarta.

Todaro, Michael P. 1998. Pembangunan Ekonomi di Dunia Ketiga, Penerbit Erlangga, Edisi Keenam, Jakarta. 